\title{
Antifungal Activity of Leaves of Cymbopogon citratus Essential Oil Against Fusarium equiseti in Culture Yam
}

\author{
Dayna Olascuaga -Vargas and Alexander Pérez -Cordero* \\ Bioprospecting Research Group Agriculture, Faculty of Agricultural Sciences, University of Sucre, \\ Sincelejo, Sucre, Colombia; dayanavargas296@gmail.com, alexander.perez@unisucre.edu.co
}

\begin{abstract}
Objective: To assess in vitro activity of essential oil of Cymbopogon citratus against Fusarium equiseti associated with yam cultivation in the department of Sucre. Materials and Methods: Two municipalities, Corozal and Tolu, each extraction of essential oils (AE) was performed, from dry and fresh leaves were sampled. $1 \mathrm{ppm}, 1.000 \mathrm{ppm}, 2.000 \mathrm{ppm}, 3.000 \mathrm{ppm}$ and $4.000 \mathrm{ppm}$ were tested, and the percent inhibition of the fungal Colonies Forming Units (CFU) was determined. Findings: The concentration of $4.500 \mathrm{ppm}$ for all oils had the highest percentages of inhibition, with a confidence level of 95\%. AE Corozal, fresh tossed lower concentrations for MIC and MCF. The chromatographic profile of the four essential oils showed the presence of terpenoids, such as citral, linalool, myrcene and $\beta$-Pinene, in which demonstrated antimicrobial and antifungal activity compounds. Application: The use of essential oil of Cymbopogon citratus, is established as an alternative future potential for management and control field tuber rot caused by Fusariumequiseti in growing yams.
\end{abstract}

Keywords: Essential Oil, Inhibition, Phytopathogen, Yam

\section{Introduction}

The yam is a crop of great economic importance, especially for the countries located in the tropics, their production and consumption on a larger scale occurs in countries such as Africa, Asia, Oceania and South Americans as Colombia, Brazil, Venezuela, Dominican Republic and Puerto Rico ${ }^{1}$. The Dioscoraceae family is represented by six to nine genera and about $600-900$ species. About 25 Dioscorea species are cited as food, 15 species as medicinal and six as ornamentals $\stackrel{1}{-}$, also used as animal feed and as raw material for industrial processes.

The yam cultivation in Colombia is grown mainly in the Caribbean region, in the departments of Córdoba, Sucre, Bolivar and Cesar, in which about 29757 ha account for over $90 \%$ of domestic production are grown, where $78 \%$ it goes to the fresh market and export $\stackrel{2}{ }$.

Because it is a crop that is not entirely industrialized and cultivated occurs mainly in small farms, the performance levels can be affected by nutritional soil depletion and the appearance of phytopathogenic mainly fungi of the genus Colletotrichum sp. and Fusarium sp, the latter causing dry rot and wilt tuber post-harvest, the synergistic action between both cause losses of up to $80 \%$ of production $^{3,4}$. However in recent decades, it has implemented the use of large amounts of fertilizers and agrochemicals but have yielded excellent results in production have caused environmental problems such as eutrophication of water sources, the emergence of strains resistant to fungicides in human and economic, cultural and social environment health. In response to this problem they have intensified

*Author for correspondence 
research into finding alternative mechanisms to achieve sustainable production and are in turn environmentally friendly. In this search, one method that has attracted important in recent years is the use of essential oils, plant secondary metabolites, which have been shown to have antifungal activity on various pathogens, including Fusarium fungi which are characterized by attack crops aggressively postharvest. Studies have shown that the essential oil of Cymbopogon citratus suppresses the growth of several species of Fusarium ${ }^{5}$, which allows us to propose the use of this metabolite to combat the disease. The objective of this study was to evaluate in vitro activity of essential oil of C. citratus against Fusariumquiseti, associated with yam cultivation in the department of Sucre. Which allows us to - propose the use of this metabolite to combat the disease. The objective of this study was to evaluate in vitro activity of essential oil of C. citratus against Fusariumquiseti, associated with yam cultivation in the department of Sucre, which allows us to propose the use of this metabolite to combat the disease.

\section{Materials and Methods}

\subsection{Study Area}

Cymbopogon citratus samples were collected at the department Sucre- Colombia, in the town of Corozal (Subregion Savannah) $9^{\circ} 75^{\circ} 17^{\prime} 55.71^{\prime \prime O} 19^{\prime} 27.74^{\prime \prime} \mathrm{N}$ and $168 \mathrm{~m}$ in the city and Tolu (Subregion Morrosquillo Gulf) $9^{\circ} 75^{\circ} 34^{\prime} 47.42^{\prime \prime} \mathrm{O} 31^{\prime} 31.26^{\prime \prime} \mathrm{N}$ and 6 meters. The sampling was carried out during the sunset, to avoid volatilization of components present in the samples also took into account that the plants were in good condition (without systemic damage).

\subsection{Study Samples}

Cymbopogon citratus samples collected were used for obtaining essential oils, which are made with fresh and dry material. For this half of the material was taken and dehydrated in an oven at $45^{\circ} \mathrm{C}$ for 24 hours, the other half was allowed to cool. 3 sets of each storage area and taxonomic confirmation in the Herbarium of the University of Sucre were taken.

\section{Obtaining Essential Oils}

The method of assisted Micro-Wave Hydro-Distillation (MWHD) $)^{6}$ was used for extraction of oils. To this
$250 \mathrm{~g}$ of each plant material they were weighed, and were deposited in the ball extraction with $250 \mathrm{~mL}$ of distilled water and subjected to the process of steam stripping using heating extraction time was 30 minutes divided into three cycles of 10 minutes each. As microwave radiation source a conventional oven (SAMSUNG AME9114ST) was used. In all cases, each essential oil was collected in a type container Dean Stark, was decanted and stored in an amber vial $4 \mathrm{~mL}$.

\section{Fungus Isolation}

The fungus was isolated from leaves showing symptoms characteristic of the disease in cultivation Yam hawthorn variety (D. rotundata) and native (D. alata) from the checkpoint Township Sincelejo-Sucre, Colombia, located $9^{\circ} 75^{\circ}$ $21^{\prime} 55.57^{\prime \prime} \mathrm{O} 17^{\prime} 56.92 \mathrm{~N}$ and $175 \mathrm{~m}$. For isolation, the methodology proposed by Finch et al was followed by ${ }^{7}$, which consisted of removing lesions small tissue fragments that were subjected to processes of disinfection sodium hypochlorite solution $5.25 \%$ for 1 minute and washed three times with sterile distilled water. The samples were dried with sterile paper towels and planted on the surface of Petri dishes containing culture medium Potato Dextrose Agar (PDA) plus chloramphenicol and incubated at $28^{\circ}$ $\mathrm{C}$ for 7 days. Daily monitoring was done and the mycelial growth with similar morphology of Fusarium sp in the new media. The strain obtained was sent to the Corpogen Corporation in Bogotá- Colombia for identification at the molecular level. Finally, in order to corroborate the pathogenicity of the isolated strain pathogenicity assay it was performed using the methodology proposed by ${ }^{\text {. }}$.

\section{In Vitro Evaluation of the Antifungal Activity of Essential Oils}

The method followed coupled microdilution colony counting proposed by ${ }^{9}$. Microdilutions (1 ppm, 1.000 ppm, $2.000 \mathrm{ppm}, 3.000 \mathrm{ppm}, 4.000 \mathrm{ppm}$ ) were made from a stock solution of $15.000 \mathrm{ppm}$ in oil, then took 100 $\mathrm{uL}$ of each dilution and placed in microwells of a plate reading ELISA containing $100 \mathrm{uL}$ of inoculum of conidia adjusted to a concentration of 104 conidia / $\mathrm{mL}$. The plate was incubated at $28 \pm 2^{\circ} \mathrm{C}$ for $24 \mathrm{~h}$, until reaching the maximum germination time. An aliquot of $40 \mathrm{uL}$ of each treatment was taken and plated in a Petri dish with PDA. 
After 48 hours incubation under a $12 \mathrm{~h}$ light cycle and $12 \mathrm{~h}$ dark at $28 \pm 2^{\circ} \mathrm{C}$, the colony count of each plate which was expressed as the number of colony forming units (CFU) it was performed.

$$
\text { \%InhibitiondeCFU }=100-\left(\frac{\text { CFUexperimental }}{\text { Control }}\right) \times 100
$$

A positive control using Benomyl 2\%, the absolute control and the negative control with distilled water and $0.2 \%$ DMSO was used with the 6 replicates of each treatment were performed. Finally the Minimal Inhibitory Concentration (MIC) was determined as the lowest concentration of the treatments showed germination inhibition $\geq 90 \%$ after 8 days of incubation and the minimal fungicidal concentration (MFC) as the lowest concentration of treatment He showed no visible growth that conidia or caused the inhibition of germination of $100 \%$ at 14 days incubation ${ }^{10}$.

\section{Chemical Characterization of the AE by Chromatography Technique Coupled to Mass Spectrometry Gases}

The determination of the chemical components of the four $\mathrm{AE}$ of $C$. citratus was performed by instrumental technique gas chromatography coupled to Mass Spectrometry (GC / MS) developed by the Laboratory of Instrumental Analysis of the National University at Medellin.

\section{Statistic Analysis}

The research was conducted under a DBCA $2 \times 5$ design with 6 replicates per treatment and statistical analysis ANOVA simple factorial arrangement with experimental sampling units, using the statistical program Statgraphics Centurion XVII. two experimental factors were assessed: the concentrations of oil in 5 levels ( 1 ppm, 1000 ppm, 2000 ppm, 3000 ppm, $4000 \mathrm{ppm}$ ) and the type of material with two levels (fresh, dry), blocking was performed by zone collection (Corozal, Tolú) and taken as the response variable percentage inhibition of CFU. Tukey test was performed to compare the difference between the averages of treatments.

\section{Results and Discussion}

\subsection{Study Samples}

The taxonomic classification by the Herbarium of the University of Sucre confirmed the identity of plants as Cymbopogon citratus. Samples from the municipality tolu are stored under voucher 000.327 and collected in the municipality of Corozal with voucher 000,326.

\subsection{Obtaining Essential Oils}

According to their origin and material condition, a total of four essential oils were obtained, two for each sampled area as well: 1) AE Corozal fresh, 2) AE Corozal dry, 3) AE Tolúfresh, and 4) AE Tolú dry.

\subsection{Isolation of the Fungus}

The results of molecular analysis by the Corpogen laboratory Bogotá, showed that the strain under study has $100 \%$ identity of its length with ITS sequences with those stored in global genomic bank corresponding to the species Fusarium equiseti. Test in vitro pathogenicity strain of Fusarium isolation was performed on fresh leaves and tubers of criollo yam (Dioscorea alata) from the nursery Costa Verde, Chinú, Córdoba, certified by the ICA, in order to ensure free material pathogen. After 20 days of incubation wilting and rotting it was observed in tissues and fungal growth on the surface thereof.

\subsection{In Vitro Evaluation of the Antifungal Activity of Essential Oils}

An absolute control (strain without any treatment), a negative control (water $+0.2 \%$ DMSO) and positive control $2 \%$ benomyl was used to evaluate in vitro antifungal activity of AE. These were mixed in Elisa plates in a 1: 1 with the solution of conidia and plated while treatments to observe differences. In counting forming units fungal colonies, a value of 223 and $222 \mathrm{CFU}$, on average, for the control and negative control respectively found, which shows no significant differences between controls and checks that DMSO $(0.2 \%)$ does not inhibit growth of the pathogen. The results obtained in the in vitro evaluation of the antifungal activity shown for all cases the percentage inhibition of CFU AE fresh is higher than that found for AE dry also the concentration at which greater inhibition observed was $4.000 \mathrm{ppm}$ (Figure 1). 


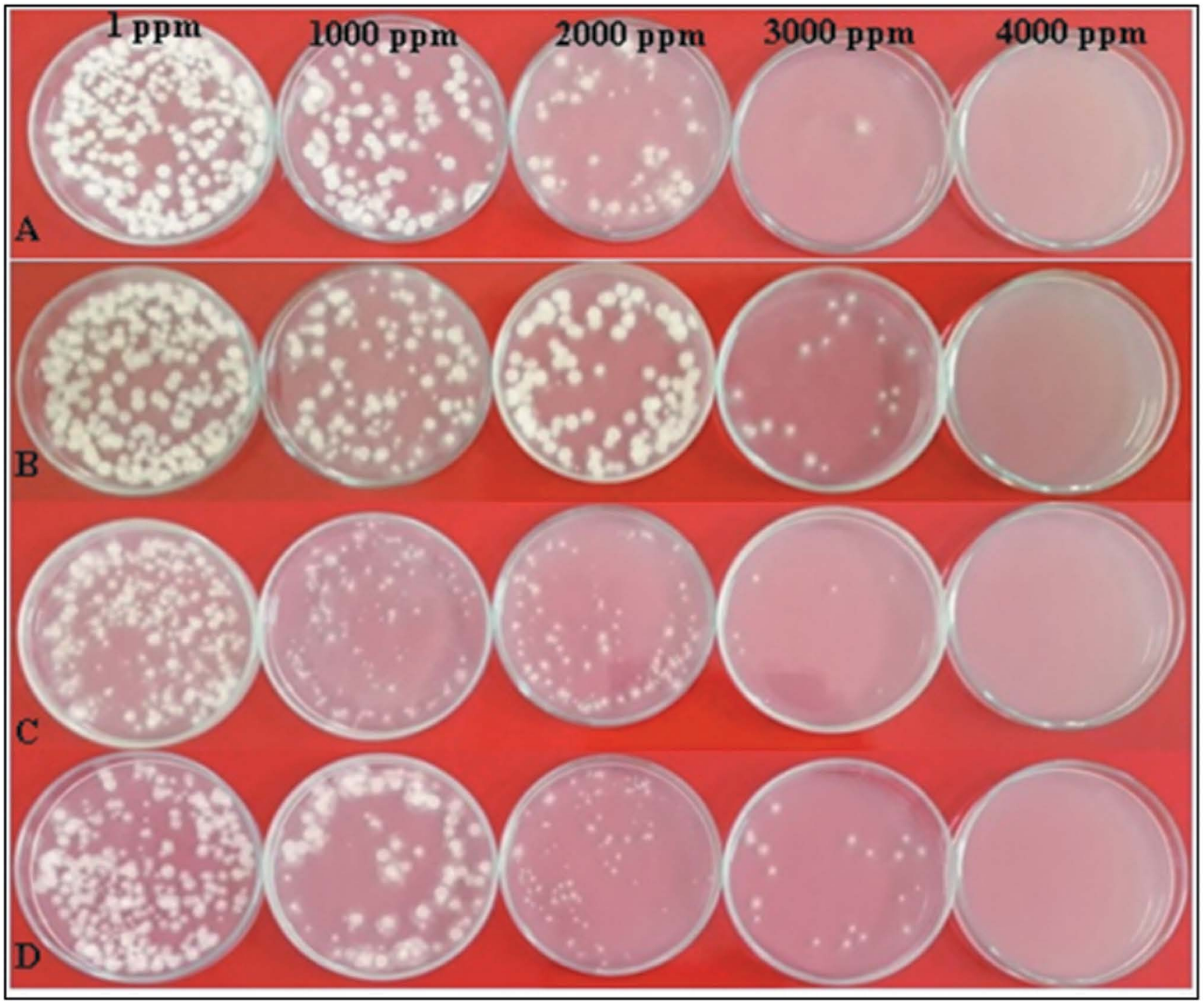

Figure 1. Antifungal activity essay of leaves of Cymbopogon citratus essential oil against Fusarium equisetiin different concentrations: 1 ppm, 1.000 ppm, 2.000 ppm, 3.000 ppm and 4.000 ppm. A. essential oil in freshof Corozal; B. essential oil in dryof Corozal; C. essential oil in freshof Tolú; D. essential oil in dryof Tolú.

Multiple range test implemented for contrast medium was Tukey HSD test, confirmed that significant differences exist in the interaction between the material types and concentrations tested against F. Equiseti (Figure 2). To determine the MIC and MFC concentrations of 3.800 ppm, $4.000 \mathrm{ppm}, 4.200 \mathrm{ppm}, 4.400 \mathrm{ppm}$ and $4.600 \mathrm{ppm}$ were used and probit analysis was performed. In the case of essential oil Corozal obtained from leaves fresh MIC was $3548.13 \mathrm{ppm}$, while the MFC was $4466.83 \mathrm{ppm}$, the oil leaves, collected in the same area, had a MIC of $3981.07 \mathrm{ppm}$ and MFC of $4570.88 \mathrm{ppm}$. In the case of the samples collected in the municipality of tolu, the essential oil of fresh leaves showed equal effect in fresh oil obtained in the municipality of Corozal (Table 1).

\subsection{Chemical Profiles of Essential Oils}

Chemical profiles evaluated essential oils showed similarities in chemical composition and concentration of metabolites, showing the presence of citral, linalool and $\beta$-Pinene in all oils except essential oil fresh Corozal containing Myrcene instead of $\beta$-pinene.

These results agree with the major components reported in C. citratus collected by 11 in the Caribbean 


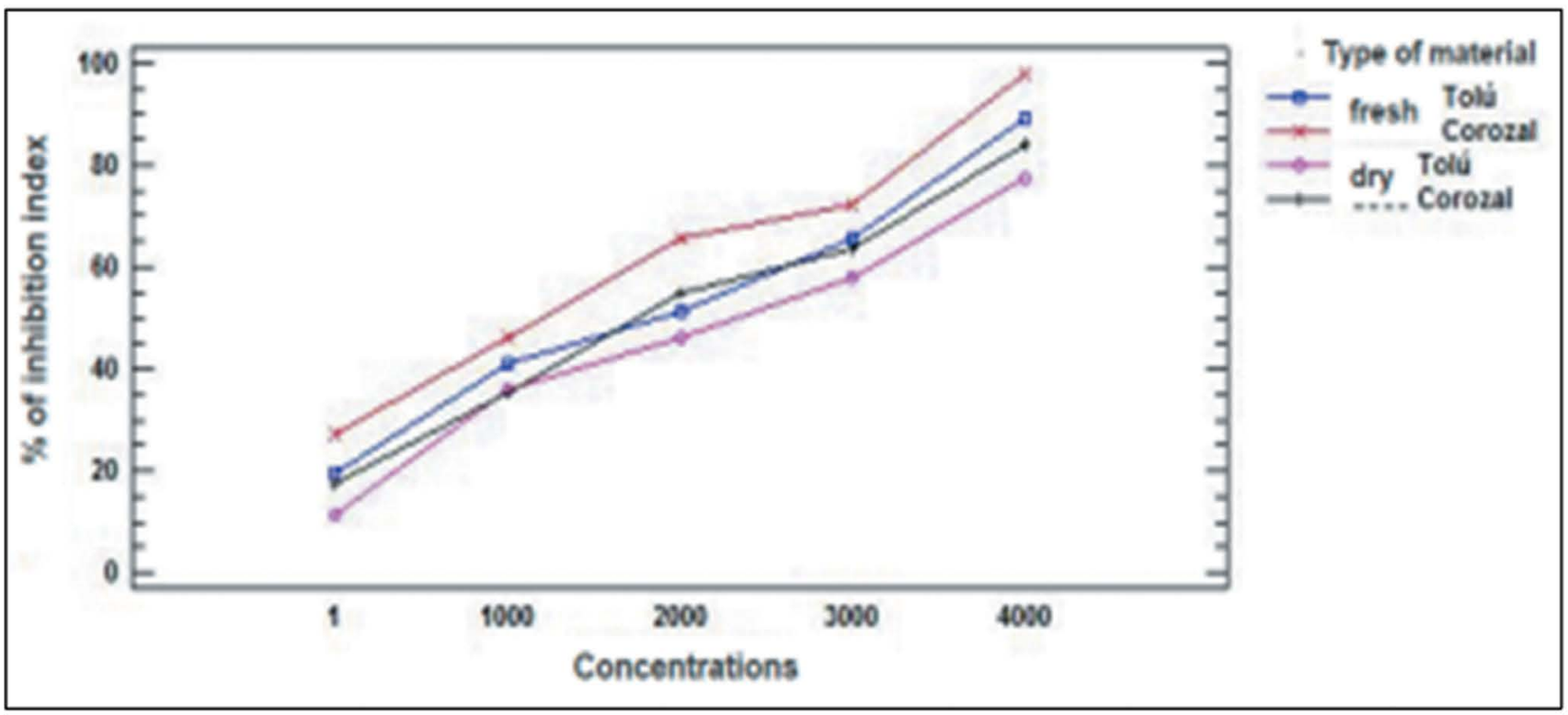

Figure 2. Interaction between the types of essential oils (fresh and dry) and the concentrations evaluatedin two municipalities (Corozal and Tolú).

Tabla 1. Probit analysis for Minimal Inhibitory Concentration (MIC) and Minimal Fungicidal Concentration (MFC) of Cymbopogon citratus against Fusarium equiseti collected from the municipalities of Tolú and Corozal

\begin{tabular}{llllll}
\hline \multirow{2}{*}{ Concentration } & \multicolumn{2}{l}{ Corozal } & & \multicolumn{2}{c}{ Tolú } \\
\cline { 2 - 3 } & essential oil fresh & essential oil dry & & essential oil fresh & essential oil dry \\
\hline CMI & 3548.13 & 4466.83 & & 3981.07 & 4570.88 \\
CMF & 3981.07 & 4570.88 & & 4168.69 & 4677.35 \\
\hline
\end{tabular}

Coast of Colombia, where Citral found in $76.70 \%$ of the oil obtained. It has been shown that abundant essential oils in Citral have bactericidal and fungicidal properties $\frac{12,13}{13}$, property increases when mixed with Myrcene ${ }^{13}$. Therefore, possibly the inhibitory effect reported in this work due to the synergism between the principal chemical constituent, citral and myrcene, the latter only present in the essential oil collected in Corozal and extracted from fresh leaves.

Most essential oils are chemically complex, which increases the efficiency because of the synergy of its components, they are generally present as mixtures of compounds, such pathogens may be affected differentially by the individual compounds or mixtures at certain concentrations and ratios. Studies conducted by $\stackrel{1,15}{1,1}$ attributed to $C$. citratus pharmacological and antimicrobial properties against taphylococcus aureus,
Bacillus cereus, Bacillus subtilis, Escherichia coli and Klebsiella pneumoniae.

The study by ${ }^{6}$ in the essential oils obtained from fresh leaves of C. citratus Sincelejo Sampués and La Union (Colombia), the major metabolite found as Citral, which was attributed to the oil a strong antifungal activity. Work carried out by ${ }^{16}$ showed that the AE C. citratus is a strong antifungal, employed 75 essential oils for the control of Fusarium oxysporum f. sp. Cicer, and found that among them were the most effective cinnamon (Cinnamomum zeylanicum), cassia (Cinnamomum cassia), cloves (Syzygium aromaticum) and lemongrass (C. citratus), showing a high inhibitory effect.

However the composition of essential oils can be affected by different environmental and artificial factors. Authors like $1^{-\frac{1-22}{2}}$, have reported the influence of the temperature of the drying process of the plants before 
the extraction process on the chemical composition and performance los essential oils of various medicinal and aromatic, such as $C$. citratus, Melaleuca alternifolia, Lippia sidoides, Lippia alba, origanoides Lippia and Thymus vulgaris plants, all conclude that in the drying process temperature directly affects the concentration of the main components of oil, but not in their chemical composition, pattern continues in this investigation as no differences in the major chemical constituents are observed but in quantity, the essential oils from dry samples have compounds at lower concentrations than those extracted from samples fresh, this is probably one of the reasons why the AE fresh samples exhibit greater inhibition than the AE dry samples. The drying temperature should be between $50^{\circ} \mathrm{C}$ and $60^{\circ} \mathrm{C}$.

Other studies have put C. citratus antifungal capabilities, are which evaluated in vitro essential oils obtained from leaves of C. citratus against Fusarium species found strong inhibition species dependent, F. equiseti for evidenced mycelial growth inhibition of $78.7 \%$ at $1500 \mathrm{ppm}^{23}$. Also, as secondary metabolite found majority to $76 \%$ Citral and work reported by ${ }^{24}$ showed this monoterpene good effect in controlling the mycelial growth and germination of C. gloeosporioides.

Findings found by $\underline{25,26}$, reported that the essential oil of C. citratus exhibited fungitoxic activity against Aspergillus flavus at a concentration of $250 \mathrm{ppm}$ of the essential oil of C. citratus showed inhibition of mycelial growth of F. oxysporum and $24.25 \mathrm{ppm}$ IC50 and MIC and MFC 62.5ppm 250 ppm.

Antifungal activity of the essential oil may be due to the presence of this monoterpene $e^{27}$, although it may also be related to the interaction between the majority component and minority ${ }^{28}$. In addition, these active compounds do not have a unique mechanism of bioactivity, but a cascade of reactions ${ }^{29}$. One possible explanation is the synergism between the diversity of chemical species present in the mixture ${ }^{30}$, since the physical properties influence significantly on the action of the components, either to increase or decrease its activity ${ }^{\underline{31}}$.

\section{Conclusions}

The use of essential oil of Cymbopogon citratus, is established as an alternative future potential for management and control field tuber rot caused by Fusarium species in growing yams. Removing any essential oil should be made from fresh plant material as the pre-treatment thereof, directly affects the quantity and quality of bioproduct.

\section{Acknowledgments}

The authors thank the University of Sucre for their collaboration in implementing research.

\section{References}

1. González M. The Yam (Dioscorea spp.) Characteristics, uses and medicinal value. Important aspects of this crop development, Cultivos Tropicales. 2012; 33(4):5-15.

2. Reina Y. The cultivation of yams in the Colombian Caribbean, Regiones. 2012; 7(2):133-158-176.

3. Green K.R, Abang MM, Iloba C. A rapid Bioassay for Screening Yam Germplasm for Response to Anthracnose, Tropical Science. 2000; 40(3):132-38.

4. Abang M, Winter S, Mignouna H, Green K, Asiedu R. Molecular taxonomic, epidemiological and population genetic approaches to understanding yam anthracnose disease, African Journal of Biotechnology. 2003; 2(12):486-96. https://doi.org/10.5897/AJB2003.000-1098.

5. Gawai D. Antifungal activity of essential oil of Cymbopogon citratus stapf against different Fusarium species, Bionano Frontier. 2015; 8(2):186-89.

6. Vitola D, Hernández J. In vitro evaluation of the efficiency of essential oils of four aromatic plants against Colletotrichum gloeosporioides (Penz.) Penz. and Sacc. cause of anthracnose in yam crops in the department of Sucre. Universidad de Sucre; 2016. p. 1-89.

7. Pinzón Y, Bustamante S, Buitrago G. Differential molecular diagnosis of Colletotrichum gloeosporioides and Fusarium oxysporum in yam (Dioscorea sp.), Revista Colombiana de Biotecnología. 2013;15(1):52-60.

8. Baquero MJ, Pérez LM, Beltrán JD. Identificación y caracterización de Colletotrichum spp como agente causal de la antracnosis en Dioscorea spp. Tesis de grado. Facultad de Educación y Ciencias. Programa de Biología. Universidad de Sucre; 2010. p. 1-62.

9. Conti S, Radicioni G, Ciociola T, Longhi R, Polonelli L, Gatti R, Cabras T, Messana I, Castagnola M, Vitali A. Structural and functional studies on a proline-rich peptide isolated from swine saliva endowed with antifungal activity towards Cryptococcus neoformans, Biochimica et Biophysica Acta. 2013; 1828(3):1066-74. https://doi. org/10.1016/j.bbamem.2012.12.013. PMid: 23274276.

10. Yazdani D, Rezazadeh S.H, Amin GH, Zainal -Abidin MA, Shahnazi S, Jamalifar H. Antifungical activity of 
dried extracts in anise (Pimpinella anisum L.) and star anise (Illicium verum Hook. f.) against dermatophyte and saprophyte fungi, Journal of Medicinal Plants. 2009; 8(5):24-29.

11. Mendoza DL, Taborda M. Chemical Composition and acaricidal activity of essential oil Cymbopongon citratus Stapf against house dust mite Dermatophagoides farinae (Acari: Pyroglyphidae), Biosalud. 2010; 9(2):21-31.

12. Pattnaik S, Subramanyam V, Kole C, Sahoo S. Antibacterial activity of essential oil of Cymbopogon: inter and intraspecific differences, Microbios. 1995; 84(341):239-45. PMid: 8643027.

13. Negrelle RRB, Gomes EC. Cymbopogon citratus (DC.) Stapf: Chemical composition and biological activities, Revista Brasileira de Plantas Medicinais. 2007; 9(1):80-92.

14. Tajidin NE, Ahmad SH, Rosenani AB, Azimah H, Munirah, M. Chemical composition and citral content in lemongrass (Cymbopogon citratus) essential oil at three maturity stage, African Journal of Biotechnology. 2012; 11(11):2685-93 https://doi.org/10.5897/AJB11.2939.

15. Irfan M, Ahmad B, Jaykumar E, Ahmad J. Antibacterial activity of lemongrass (Cymbopogon citratus) oil against some selected pathogenic bacterias, Asian Pacific Journal of Tropical Medicine. 2010; 3(7):535-38. https://doi. org/10.1016/S1995-7645(10)60129-0.

16. Pawar VC, Thaker VS. Evaluation of the anti-Fusarium oxysporum $\mathrm{f}$. sp cicer and anti-Alternaria porri effects of some essential oils, World Journal of Microbiol Biotechnol. 2007; 23(8):1099-106. https://doi.org/10.1007/s11274-006-93396.

17. Martins PM. Influência da temperatura e da velocidade do ar de secagem no teor e da composição química do óleo essencial de capim-limão (Cymbopogon citratus (D.C) STAPF. Viçosa, MG. Maestría en Ingeniería Agrícola. Universidad Federal de Viçosa; 2000.

18. Barbosa F, da F, Barbosa LCA, Melo EC, Mendes BF, Santos RHS. Influência da temperatura do ar de secagem sobre o teor e a composição química do óleo essencial de Lippia alba (Mill) N. E. Brown, Química Nova. 2006; 29(6):1221-25. https://doi.org/10.1590/S0100-40422006000600014.

19. Mejía O, Marcial J, Sánchez MS, Bonilla CR, Vanegas P. Effect of height and frequency of cutting and drying on the performance and quality of the essential oil of early relief, Scientia Et Technica. 2007; 23(33):253-55.

20. Lemos DH. Influencia da temperatura do ar de secagem no teor e na composição química do óleo essencial de Melaleuca alternifólia Cheel. Tesis Maestría en Ingeniería Agrícola. Universidad Federal de Viçosa. Viçosa - MG; 2008. p. 1-55. PMid: 18764989.

21. Randünz LL, Melo EC, Rocha PP, Berbert PA, Gracia LMN. Study of essential oil from guaco leaves submitted to differ- ent drying air temperature, Ingeniería y Agricultura. 2010; 18(3):241-47.

22. Delgado J, Sánchez M, Bonilla C. Effects of drying and age plants on the composition of the essential oils of Lippia alba (Mill.) N.E.Br. ex Britton \& P. Wilson and Lippia origanoides Kunth accessions, Acta Agronómica. 2015; 65(2):170-75. https://doi.org/10.15446/acag.v65n2.47576.

23. Rocha RP. Avaliação do teor e da composição do óleo essencial de Cymbopogon citratus e Thymus vulgaris submetidos a processos de secagem e armazenamento. Tesis de Doctorado en Ingeniería Agrícola) - Universidad Federal de Viçosa - MG; 2011. p. 1-167.

24. Palhano FL, Vilches TT, Santos RB, Orlando MT, Ventura JA, Fernandes P. Inactivation of Colletotrichum gloeosporioides spores by high hydrostatic pressure combined with Citral or lemon grass essential oil, International Journal of Food Microbiology. 2004; 95(1):61-66. https://doi.org/10.1016/j.ijfoodmicro.2004.02.002. PMid: 15240075.

25. Kumar S, Mishra R.K, Kumar A, Srivastava S, Chaudhary S. Regulation of stipule development by cochleata and stipule-reduced genes in pea (Pisumsativum), Planta. 2009; 230(3):449-58. https://doi.org/10.1007/s00425-009-09520. PMid: 19488780.

26. Sharma A, Rajendran S, Srivastava A, Sharma S, Kundu B. Antifungal activities of selected essential oils against Fusarium oxysporum f. sp. lycopersici 1322, with emphasis on Syzygium aromaticum essential oil, Journal of Bioscience and Bioengineering. 2016; 20(20):1-6.

27. Gupta D, Bhardwaj R, Gupta RK. In vitro antioxidant activity of extracts from the leaves of Abies Pindrow Royle, African Journal of Traditional, Complementary and Alternative Medicines. 2011; 8(4):391-97.

28. Nazarro F, Fratianni F, De Martino L, Coppola R, yDe Feo V. Effect of essential oils on pathogenic bacteria, Pharmaceuticals. 2013; 6(12):1451-74. https:// doi.org/10.3390/ph6121451. PMid: 24287491, PMCid: PMC3873673.

29. Burt S. Essential oils: Their antibacterial properties and potential applications in foods-A review, International Journal of Food Microbiology. 2004; 94(3):223-53. https://doi.org/10.1016/j.ijfoodmicro.2004.03.022. PMid: 15246235.

30. Edris A.E. Pharmaceutical and therapeutic potentials of essential oils and their individual volatile constituents: A review, Phytotherapy Research. 2007; 21(4):308-23. https:// doi.org/10.1002/ptr.2072. PMid:17199238.

31. Koroch A, Juliani, R, Zygadlo J. Bioactivity of Essential Oils and their Components. Flavours and Fragrances: Chemistry, Bioprocessing and Sustainability; 2007. p. 87-103. 